Vol. 4, No. 4, 2019

\title{
IDENTIFYING THE POTENTIAL OF USING THE IMMOBILIZED MICROORGANISMS AND PERIPHYTON ORGANISMS INSTALLED ON A FIBROUS CARRIER OF THE "VIYA" TYPE FOR BIOLOGICAL TREATMENT OF INDUSTRIAL WASTEWATER DISCHARGED BY THE ENTERPRISES OF THE MINING AND METALLURGICAL COMPLEX
}

\author{
Kostiantyn Dombrovskyi ${ }^{1}$, Oleksander Rylskyi ${ }^{1}$, Petro Gvozdyak ${ }^{2}$, Kristina Krupeu ${ }^{3}$ \\ ${ }^{1}$ Zaporizhzhia National University, \\ 66, Zhukovsky Str., Zaporizhzhia, 69600, Ukraine \\ ${ }^{2}$ A. V. Dumansky Institute of Colloid and Water Chemistry of the National Academy of Science of Ukraine, \\ 42, Academician Vernadsky Ave., Kyiv, 03142, Ukraine \\ ${ }^{3}$ Zaporizhzhya educational complex No. 63 of Zaporizhzhya city Council, \\ 12 A, Parkhomenko Str., Zaporizhzhya, 69071, Ukraine \\ dombrov1717@ukr.net,rylsky@ukr.net, \\ gvozdyak@ukr.net, krupeyznu@gmail.com
}

https://doi.org/10.23939/ep2019.04.185

Received: 24.09.2019

(C) Dombrovskyi K., Rylskyi O., Gvozdyak P., Krupeu K., 2019

\begin{abstract}
The article deals with the problem of surface water pollution by untreated industrial wastewater, namely oil products, using clarifiers applied by the "Zaporizhstal" PJSC plant in the city of Zaporizhzhya. The survival of gram-positive bacterial colonies and periphyton immobilized on a fibrous carrier in the wastewater of the sludge collector was experimentally observed, taking into account the optimal ambient temperature ideal for the life of microorganisms (within the range of $25.0-27.5^{\circ} \mathrm{C}$ during the summer period).
\end{abstract}

Key words: effluent, sludge collector, fibrous carrier, immobilized microorganisms, organisms contained in periphyton.

\section{Introduction}

Ferrous metallurgy of Ukraine is among the most significant consumers of water in the national economy of the country. Despite the fact that the metallurgical enterprises of Ukraine make extensive use of recyclable water supply, the share of which exceeds $80 \%$, the amount of wastewater discharged into the water bodies is still quite significant and exceeds 1.5 billion $\mathrm{m}^{3} /$ year [1].

Since the sludge collectors of metallurgical enterprises in Ukraine are a part of the production technology of the metallurgical industry, they tend to occupy large areas, reaching tens and hundreds of millions of cubic meters in volume. They are a significant source of negative impact on the environment.

It is known that in the Dnieper basin there are 3 main zones of pollution of surface and ground water, which were formed under the influence of technogenic intervention [2]. In the area of the mining and metallurgical complex located in the basin of the middle reaches of the Dnieper River, there are more than 350 reservoirs, 279 of which are sludge collectors and 22 are tailings ponds. The latter are used as reservoirs for collecting effluents of solely industrial origin [3].

Oils that enter industrial wastewater are used by metallurgical enterprises as a lubricant for various types of machinery (e.g. hot rolling mills), as well as in other technological processes. During the rolling process, at each technological operation, the water is heated, contaminated with mill scale, lubricants and dumped into a tunnel, located under the central roller table, and then - into a settling tank (clarifier) for scale. It has been established that the amount of oil in the sediment from the mill scale pit amounts to $1 \%$ of the total weight of the scale, whereas the sludge from the secondary clarifiers contains around 10-20\% [4]. These are usually petroleum oils that contain a mixture of various hydrocarbons and additives.

Process flow charts for the purification of oilcontaining wastewater in our country and abroad involve 
mixing of all types of oil-containing effluents and their settling [4]. Waste oils that have been used in industry require proper disposal. Different methods (mechanical, thermal, physicochemical, thermochemical and biological) are used for the purpose of utilization of waste petroleum products [5]. It is well known that priority is given to the use of biotechnology in current scientific research, since biological methods ensure the simultaneous environmental friendliness and economic profitability of wastewater treatment. The appeal of biological treatment lies in the unique ability of microorganisms to adapt under the most extreme and unfavorable circumstances [6].

The analysis of biological methods of industrial wastewater treatment shows the advantage of biotechnology that uses fibrous carriers with immobilized microorganisms [7]. It has been shown that the immobilized microorganisms can reach extremely high levels of concentration of cells per unit surface of the carrier and are more stable and effective than the microorganisms living within the water column of the treatment plant. Therefore, this method of industrial wastewater treatment does not require the remodelling of existing wastewater treatment plants and makes it possible to intensify the processes of biological wastewater treatment. The information on the use of such biotechnologies for the effective purification of surface and waste waters using immobilized microorganisms and organisms contained in periphyton on a fibrous carrier of the "VIYA" type is presented in [8-10].

The aim of this study is to substantiate the biotechnology of industrial wastewater treatment of effluents contained in the Kapustianka gully sludge collector, that belongs to the "Zaporizhstal" PJSC metallurgical plant, from petroleum products through the use of microorganisms immobilized on a fibrous carrier and periphyton organisms.

\section{Experimental part}

Zaporizhzhia region has a powerful industrial capacity that is manifested in the form of metallurgical, mining, machine-building and chemical complexes. "Zaporizhstal" PJSC is the largest polluter of water supply both in the city and the entire region. The overall share of the plant in the total amount of discharge of contaminated return water in the region amounts to $85 \%$.

As far as enterprises of the Zaporizhzhia industrial site are concerned, including "Zaporizhstal" PJSC plant, the discharge of wastewater occurs mainly through the Kapustyanka gully, where wastewater is concentrated and settled, which allows us to reduce to a certain extent the content of slurry and insoluble oils, but it does not solve the problem of progressing pollution of the Dnieper River. The sludge that accumulates in the gully is fed by dredges to the sludge accumulator for long-term storage, which is located on the Horodyska gully at a distance of $30 \mathrm{~km}$ from the Kapustianka gully [1]. From the Horodyska gully sludge collector clarified water is fed back to the Kapustyanka gully catch basin and discharged into the lower canal pond and further into the Dnieper River (upper Kakhovka reservoir). The volume of return water discharge into the water supply of the "Zaporizhstal" PJSC plant amounted to 69.30 million $\mathrm{m}^{3} /$ year in 2015 , including contaminated water, and through the Kapustianka gully off-site sludge disposal complex it was 59.51 million $\mathrm{m}^{3} /$ year.

The sewage treatment, which is carried out between production cycles at the plant, does not allow removal and disposal of all pollutants, as evidenced by the results of an independent laboratory study of the surface waters in the region [11].

The efficiency of integrated use of fibrous carrier of the "VIYA" type for the purification of industrial wastewater was tested under the conditions of a hydraulic structure (Kapustyanka gully clarifier of industrial wastewater), which belongs to the "Zaporizhstal" PJSC plan off-site sludge disposal complex.

A 10.5 million $\mathrm{m}^{3}$ storage facility was designed by Kharkiv "Vodokanalproekt" (Ukraine). Industrial wastewater and sludge discharge capacity is around 1.1 million tons / year, service life - 25 years, area of the sludge collector 135 hectares, which has been in operation since 1958. The sludge collector is designed to process industrial wastewater and sludge of the "Zaporizhstal" PJSC plant (sludge obtained through wet gas scrubbing at a sinter plant, blast furnaces, open-hearth furnaces, machines for casting cast iron, sewage from TPPs, water influx of scale from rolling mills, foundries, waste emulsions, etc.) [3]. In addition to the sewage from "Zaporizhstal" PJSC plant, the sludge collector collects wastewater from a number of enterprises, in particular: "Dniprospetsstal" PJSC, "Zaporizhzhia Aluminum Combine” PJSC, "Zaporizhzhia Steel Rolling Plant" PJSC, "Kremniypolimer" ZSE, "Zaporizhkoks" PJSC.

In 1979, a circulating cycle of industrial wastewater of the NTLS-1680 thick-sheet hot rolling mill was put into operation. Prior to this, the effluents polluted with scale and oils were discharged into the sludge collector after being processed in presettling tanks. Taking into account that the system of a circulating cycle entrapped around 12.000 tons of scale / per year on average, during the period from 1958 to 1979 the oxide scale that was contained in industrial wastewater was being accumulated in the Kapustianka gully channel, and after 20 years its mass reached the mark of around 252 thousand tons [3].

To ensure the intensification of biological sewage treatment of the sludge collector, three rafts with fibrous 
carrier of the "VIYA" type were installed on the surface of the artificial reservoir. Fibrous carrier rafts were placed in a hydraulic structure so that the fibrous carrier was continuously in the surface layer of water, accumulating the immobilized (attached) microfauna of the aquatic organisms during the period of July-August, 2018, Fig. 1. Floating carrier elements in the shape of a "raft" were characterized by the following dimensions $-1.50 \times 0.54 \mathrm{~m}$.

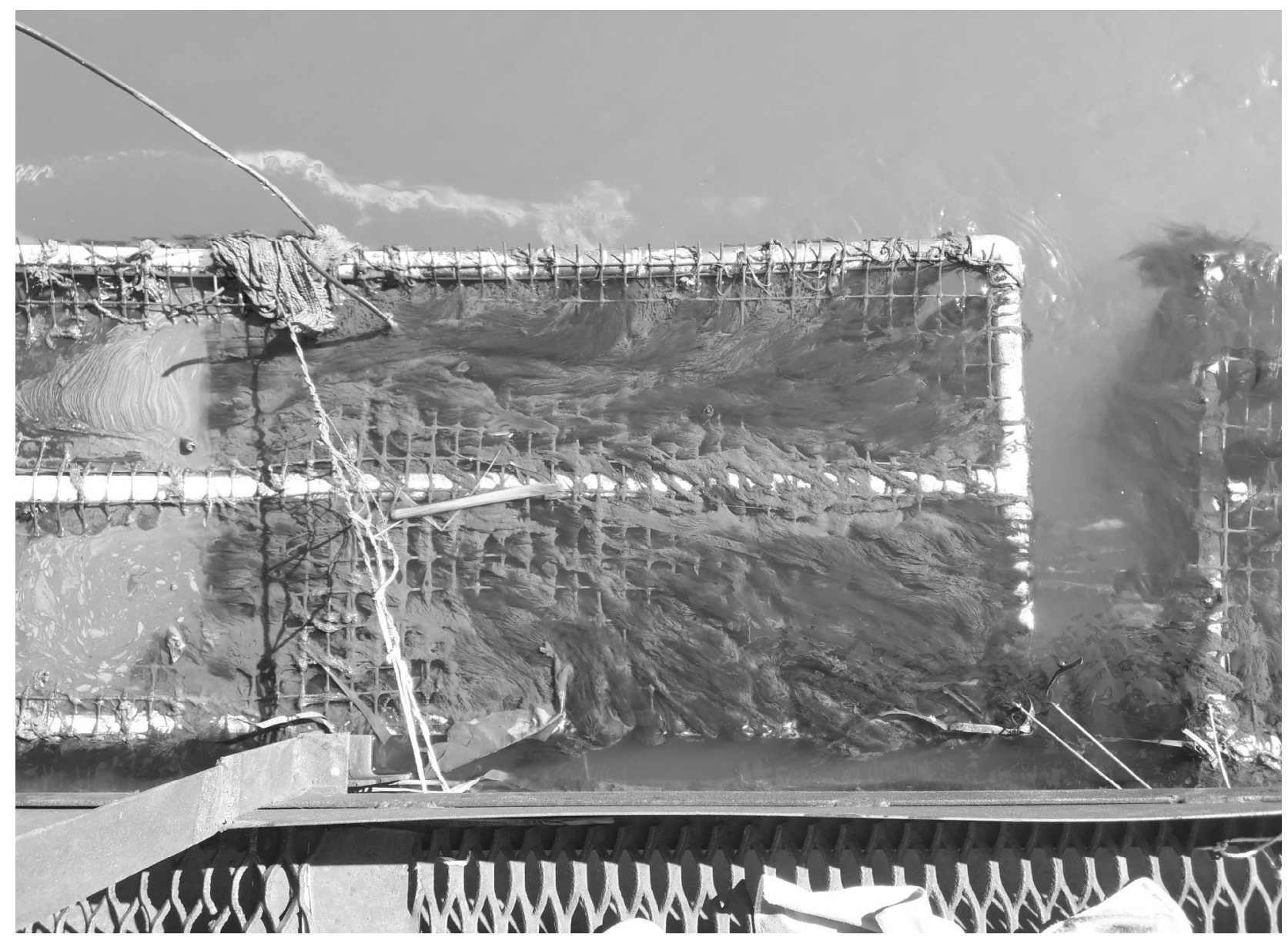

Fig. 1. Rafts with fibrous carrier of the "VIYA" type installed at the sludge collector of the "Zaporizhstal" PJSC plant

The primary immobilization of microorganisms and other aquatic organisms on a fibrous carrier was performed at the stormwater treatment facilities ZTF No. 54 of the "Motor Sich" PJSC plant, where natural selection of immobilized destructor-bacteria that eliminate petroleum products has been taking place for 2 years. Then, the fibrous carrier with the immobilized organisms was removed from the treatment facility of the motor-building plant and transported to the hydraulic structure, where it was placed near the already installed rafts equipped with a nozzle of the "VIYA" type.

During the period of July-August, 2018, the chemical composition and physical properties of wastewater were determined, where bacteriological and hydrobiological studies of the "VIYA" fibrous carrier biofilm were conducted under the conditions of a sludge collector.

The number of microorganisms was determined using the standard method in aqueous microbiology by seeding of sequential dilutions of aqueous suspension on standard nutrient media [12]. Studies of microbial colonies were carried out after 2 days of cultivation, beginning with the identification of available morphotypes. Each type of colony was assigned a number, its colour, size and shape were described. The most isolated and visible colonies of each morphotype were labeled and smeared for microscopic examination. After the preparation of smears from the marked colonies, Gram staining was performed. In the presence of pure cultures, the microorganisms were transplanted onto the mowed agar for storage in the collection. For further stages of identification of microorgansms-destructors, Berji Bacteria Determinant was used

Thus, laboratory studies of bacterial cultures included a series of the following sequential operations: inoculation of the test material (water suspension), cultivation of the material, selection of pure culture, identification of culture.

Hydrobiological material (periphyton installed on a fibrous carrier of the "VIYA" type) was selected according to the method described by us previously [9]. 
The calculation of the number of periphyton organisms of the fibrous carrier was carried out taking into account the surface area of the substrate and was expressed in specimens $/ \mathrm{m}^{2}$. First, the area of a single fiber was determined, that is, the area of the cylinder, and then the area of the substrate was recalculated taking into account the number of cut fibers. The number of fouling organisms in a given volume $(0.1-0.3 \mathrm{ml})$ was then determined and their quantity was recalculated adjusted for the total volume of a sample $(50-60 \mathrm{ml})$.

Studies of the chemical composition of water were conducted in the laboratory of environmental protection of the "Zaporizhstal" PJSC plant.

\section{Results and discussion}

The chemical composition and physical properties of water from industrial effluents contained in a sludge collector fluctuated within certain limits, in $\mathrm{mg} / \mathrm{dm} 3$ : total iron - 0.61-0.91; petroleum products 0.193-0.214; organic pollution by biochemical oxygen consumption $\left(\mathrm{BOC}_{5}\right)-4.20-4.30$ and by chemical oxygen consumption (COC) - 32.40-33.20; hydrogen index $(\mathrm{pH})-7.54-8.10$; the total amount of suspended solids is 8.7-11.0. The values of dissolved oxygen and redox potential (ORP) of wastewater ranged from 3.7 to $5.7 \mathrm{mgO}_{2} / \mathrm{dm}^{3}$ and from $+170 \mathrm{mV}$ to $+286 \mathrm{mV}$, respectively. Water temperature of industrial wastewater fluctuated within $25.0-27.5{ }^{\circ} \mathrm{C}$, see Table 1.

During the study of the redox characteristics of the sludge collector wastewater we have determined that the values of the ORP of water increase from July to August, and the capacity of the redox system in terms of $\mathrm{rH}_{2}$ corresponds to favorable conditions for the oxidative and oxidative-destructive purification processes.

Table 1

Characteristics of the main chemical and physical components of effluents found in a sludge collector in 2018

\begin{tabular}{|c|c|c|c|c|c|c|c|c|}
\hline \multirow{2}{*}{ Indicators } & \multicolumn{8}{|c|}{ Sampling date } \\
\hline & 04.07 & 06.07 & 23.07 & 01.08 & 09.08 & 13.08 & 28.08 & MAR \\
\hline Total iron, $\mathrm{mg} / \mathrm{dm}^{3}$ & 0.70 & 0.91 & 0.79 & 0.90 & 0.80 & 0.61 & 0.76 & 0.295 \\
\hline Petroleum products, $\mathrm{mg} / \mathrm{dm}^{3}$ & 0.193 & - & - & 0.214 & - & - & - & 0.166 \\
\hline $\mathrm{BOC}_{5}, \mathrm{mgO}_{2} / \mathrm{dm}^{3}$ & 4.20 & - & - & 4.30 & - & - & - & 3.796 \\
\hline $\mathrm{COC}, \mathrm{mgO}_{2} / \mathrm{dm}^{3}$ & 32.4 & - & - & 33.2 & - & - & - & 22.39 \\
\hline Suspended solids, $\mathrm{mg} / \mathrm{dm}^{3}$ & 9.4 & 8.7 & 9.4 & 10.0 & 9.0 & 9.0 & 11.0 & 5.9 \\
\hline ORP, mV & +180 & +170 & +235 & +270 & +286 & - & - & - \\
\hline $\mathrm{pH}$ & 7.96 & 7.87 & 7.99 & 7.71 & 7.96 & 7.54 & 8.10 & $6.5-8.5$ \\
\hline$r \mathrm{H}_{2}$ & 22.13 & 21.60 & 24.08 & 24.73 & 25.78 & - & - & - \\
\hline Dissolved oxygen, $\mathrm{mgO}_{2} / \mathrm{dm}^{3}$ & 4.2 & 5.7 & 3.7 & - & - & - & - & - \\
\hline Temperature, ${ }^{\circ} \mathrm{C}$ & 27.5 & 27.5 & 27.5 & 27.0 & 25.0 & 27.0 & 27.0 & - \\
\hline
\end{tabular}

Note: $(-)-$ the figure was undetermined

In order to determine the sanitary status of the hydraulic structure and to clarify the issue of the process of immobilization (attachment) of microorganisms on the fibrous carrier of the "VIYA" type, we have determined a microbiological indicator - the total number of microorganisms in the wastewater of the hydraulic structure and on the fibrous carrier, see Table 2.

According to the results obtained in accordance with bacteriological indicators it was found that the total number of microorganisms on the fibrous carrier was high.

Bacteriological indicators of wastewater of the hydraulic structure varied within wider limits. Thus, at the beginning of August, the total number of microorganisms of wastewater was at a level of $513.333 \times 106$ cells $/ \mathrm{cm}^{3}$, and in the first decade of August it decreased 9-fold and thus amounted to $56.500 \times 106 \mathrm{cells} / \mathrm{cm}^{3}$. It should also be noted that, on average, the total number of microorganisms on the fibrous carrier was 2.3 times higher than in the effluents found in a sludge collector over the entire study period. Among the bacteria isolated from the biofilm, specimens of the Pseudomonas, Flavobacterium, Arthrobacter and Bacillus genera were found. The vast majority of bacteria were represented by the last two genera. Taking into account the peculiarity of wastewater contained in the sludge collector, we consider that species of the Bacillus and Arthrobacter are edifiers that provide favorable conditions for the existence of consorts.

The assessment of the sanitary status of the sludge collector by the total number of microorganisms was carried out based on the assessment scale for fishery reservoirs [12]. According to this scale, the water of the hydraulic structure belongs to the "Polluted (hypersaprobic water)" category at the beginning of August and to the "Polluted (polysaprobic water)" category at the end of the first decade of August. According to the $\mathrm{BOC}_{5}$ indicator, the water of the hydraulic structure also belongs to the "Polluted" water category $\left(\mathrm{BOC}_{5}>4.0 \mathrm{mgO}_{2} / \mathrm{dm}^{3}\right)$. 
Table 2 and varieties), nematodes (1 species) and the turbellaria

The total number of microorganisms $\left(106 \mathrm{cells} / \mathrm{cm}^{3}\right)$ in wastewater and on the "VIYA" fibrous carrier installed on the sludge collector of the "Zaporizhstal" PJSC plant

\begin{tabular}{|l|c|c|c|}
\hline \multirow{2}{*}{ Object of study } & \multicolumn{3}{|c|}{ Sampling date } \\
\cline { 2 - 4 } & 23.07 .2018 & 01.08 .2018 & 09.08 .2018 \\
\hline Industrial effluents & - & 513.333 & 56.500 \\
\hline Fibrous carrier & 726.667 & 596.667 & - \\
\hline
\end{tabular}

Note: $(-)$ - the total number of microorganisms was not being determined

Analysis of the morphological structure of bacterial colonies (grown on a MPA medium) showed that all isolated colonies belong to gram-positive bacteria, which are characterized by a smooth surface and a soft texture, see Table 3.

The periphyton of the fiber carrier installed at the sludge collector of the "Zaporizhstal" PJSC plant consisted of 20 taxa of hydrobionts, which belong to three functional groups - protistoperiphyton, microzooperiphyton and macrozooperiphyton. Protistoperiphyton was represented by most species (11) belonging to three taxa. Microzooperiphyton was represented by the rotifers ( 3 species
(1 species). The macrozooperiphyton group consisted of oligochaeta (2 species), gastropod molluscs (1 species), and dragonfly larvae (1 species),

Describing the species composition and the number of organisms in the periphyton attached to the "VIYA" fibrous carrier installed on the sludge collector, it should be noted that on the 19th day after the installation of "rafts" with a fibrous carrier, the periphyton was represented by the greatest number of species and the number of specimens - 15 taxa and 1196.56 thousand specimens $/ \mathrm{m}^{2}$, respectively. Zoocenosis of the periphyton was characterized by the dominance in the number of Rotifera, which accounted for $48 \%$ of the total number. The number of ciliates and oligochaetae in the periphyton was lower $-21 \%$ and $15 \%$, respectively.

The periphyton groupings found in the fibrous carrier on the 23rd day since the exposure were represented by 12 species and the maximum number of organisms was 1504.467 thousand specimens $/ \mathrm{m}^{2}$. In the periphyton under study, Rotifera were significantly more numerous and accounted for $84 \%$ of the total number of organisms in the zoocenosis. The number of ciliates, oligochaetae and nematodes was low and varied within $4-5 \%$ of the total number of organisms in the periphyton.

\section{Morphological description of colonies of microorganisms detected on the fibrous carrier installed on the sludge collector of the "Zaporizhstal" PJSC plant}

\begin{tabular}{|c|l|c|l|l|l|}
\hline № & \multicolumn{1}{|c|}{ Shape } & Size, $\mathrm{mm}$ & \multicolumn{1}{c|}{ Colour } & \multicolumn{1}{c|}{ Edges } & Morphology \\
\hline \multicolumn{5}{|c|}{23.07 .2018} \\
\hline 1 & regular & 4 & translucent & even & Gr+ non-spore-forming bacilli of medium size \\
\hline 2 & elliptical & 11 & milky & even & Gr+ non-spore-forming bacilli of medium size \\
\hline 3 & regular & 5 & white & fringe & Gr+ bacilli with a central disposition of spores \\
\hline \multicolumn{7}{|c|}{01.08 .2018} \\
\hline 4 & regular & 5 & milky & even & Gr+ spore-forming ("drum-stick") bacilli \\
\hline 5 & irregular & 27 & translucent & wavy & Gr+ non-spore- and spore-forming bacilli \\
\hline 6 & regular & 11 & milky & even & Gr+ barrel-shaped bacilli \\
\hline
\end{tabular}

\section{Structural characteristics of periphyton attached to the fibrous carrier of the "VIYA" type installed at the sludge collector of the "Zaporizhstal" PJSC plant}

\begin{tabular}{|c|c|c|c|}
\hline \multirow{2}{*}{ Indicators } & \multicolumn{3}{|c|}{ Exposure period of the "VIYA" fibrous carrier } \\
\hline & on the $19^{\text {th }}$ day & on the $23^{\text {rd }}$ day & on the $40^{\text {th }}$ day \\
\hline \multicolumn{4}{|c|}{ Taxonomic structure (number of species) } \\
\hline \multicolumn{4}{|l|}{ 1. Protistoperiphyton } \\
\hline Mastigophora & - & $8.25 \%(1)$ & - \\
\hline Heliozoa & $6.75 \%(1)$ & - & - \\
\hline Ciliophora & $40.0 \%(6)$ & $33.0 \%(4)$ & $40.0 \%(2)$ \\
\hline \multicolumn{4}{|l|}{ 2. Microzooperiphyton } \\
\hline Rotatoria & $20.0 \%(3)$ & $17.0 \%(2)$ & $15.0 \%(1)$ \\
\hline Nematoda & $6.75 \%(1)$ & $8.25 \%(1)$ & $15.0 \%(1)$ \\
\hline Turbellaria & - & $8.25 \%(1)$ & - \\
\hline \multicolumn{4}{|l|}{ 3. Macrozooperiphyton } \\
\hline Oligochaeta & $13.0 \%(2)$ & $17.0 \%(2)$ & $15.0 \%(1)$ \\
\hline Odonata (larvae) & $6.75 \%(1)$ & - & - \\
\hline Gastropoda & $6.75 \%(1)$ & $8.25 \%(1)$ & - \\
\hline Total number of species & 15 & 12 & 5 \\
\hline
\end{tabular}


In general, the study of periphyton attached to the "rafts" of the "VIYA" fibrous carrier during July-August in 2018 showed that species biodiversity and the number of organisms in a grouping were high on the 19th and the 23rd days of our study, but afterwards the species composition of periphyton decreased from 15 to 5 species by the 40th day of the exposure. The number of organisms in the periphyton attached to the fibrous carrier also decreased significantly, almost 3-fold. Thus, the number of Rotifera and Oligochaeta in the zoocenosis decreased almost 25-fold and 3-fold, respectively, compared to the initial indicators. The number of nematodes, on the contrary, increased 3.3 times.

The decrease in the qualitative and quantitative characteristics of the periphyton attached to the "VIYA" fibrous carrier can be explained by the fact that the placement of "rafts" with fibrous media under the conditions of a rapid flow of wastewater (significant flow), microscopic fibers of the capron carrier ( $3 \mu \mathrm{m}$ in diameter) quickly become clogged with slurry from the sledge collector due to the constant work of dredgers. Also, on the 40th day of exposure, it could be seen with a naked eye that the fibrous carrier during this time concentrated a large amount of waste oils and was completely immersed in them. Thus, these factors coupled together adversely affect the development of the immobilized microbiota and periphyton on a fibrous media.

In general, during the study of periphyton found on the fibrous carrier "rafts" installed at the sludge collector during the summer period, we have identified the environment-forming complex of periphyton species. These include 4 species and forms represented by rotifers (2 taxa) - Macrotrachela qudricornifera Milne and Rotaria rotatoria rotatoria (Pallas), ciliates - Aspidisca cicada (Muller) and oligochaetae - Chaetogaster setosus Svetlov.

The results of our study within two months have shown that the process of immobilization of bacterial biota and organisms of periphyton occurs on the fibrous carrier that is installed at the sludge collector of the "Zaporizhstal" PJSC plant, which may allow further research to clarify the issue of biological purification of industrial wastewater from petroleum products. This has been confirmed by bacteriological and hydrobiological studies.

\section{Conclusions}

1. It is established that the process of biofouling of a thin chemically textured fiber of the "VIYA" type during the summer period in the effluents of the Kapustianka gully sludge collector of the "Zaporizhstal" PJSC plant is intense enough to allow the use of the system of "rafts" to eliminate petroleum products.
2. The great biodiversity of bacterial biota and functional groups of periphyton in the biofilm of the fibrous carrier under favourable thermal conditions of wastewater $\left(25-27^{\circ} \mathrm{C}\right)$ indicates that the biofilm establishes stable trophic bonds, which is the key to the long-term existence of the biofilm.

3. The decrease in the qualitative and quantitative characteristics of the periphyton attached to the "VIYA" fibrous carrier during the 40th day of exposure by the "rafts" in the hydraulic structure under study is due to the intensive adsorption of suspended slurry particles, which reduced the access of organic substances (nutrient medium) to the bacterial biota of the biofilm itself.

4. The results obtained during the study experimentally confirm the possibility of using the proposed biotechnology to reduce the concentration of petroleum products and other organic contaminants in the wastewater of the sludge collector, but it is necessary to take into account the factor of periodic increase of suspended slurry particles in the water in some individual parts of the hydraulic structure.

\section{References}

[1] Syrovats'kyj O. A.: avtoref. dys. ... kand. techn. nauk: 05.23.04. Charkiv, 1997. 16.

[2] Kasymov A. M.: Černaja Metallurhyja, 2011, 12 (1344), 70.

[3] Kasymov A. M., Stalynskaja Y. V., Sorokyna E. B.: Vostočno-Evropejskyj Žurnal Peredovыch Technolohyj, 2017, 3, No. 10 (87), 41. (in Ukrainian) https://doi.org/10.15587/1729-4061.2017.101388

[4] Avramenko S. Ch., Nenaševa O. I., Sidorova I. V.: Zbirnyk Naukovych Prac' Dniprodzeržyns'koho Techničnoho Universytetu (technični nauky), 2014, 1(24), 269. (in Ukrainian)

[5] Fylatov D. A., Svarovskaja L. Y., El'čanynova E. A. Ovsjannykova V. S., Altunyna L. K.: Neftechymyja, 2015, 55, No. 3, 253.

[6] Rebrykova P. A., Sablij L.A.: Naukovo-praktyčnyj Žurnal "Ekolohični nauky", 2018, 1, No. 1(20), 44. (in Ukrainian)

[7] Hvozdjak P. Y., Dmytrenko H. P., Kulykov N. Y.: Chymyja y Technolohyja Vodы, 1985, 7, No. 1, 64. (in Ukrainian)

[8] Rylsky A. F., Dombrovskii K. O., Krupey K. S., Petrusha Yu. Yu.: Journal of Water Chemistry and Technology, 2016, 38, No. 4, 232. https://doi.org/ $10.3103 / \mathrm{s} 1063455 \times 16040081$

[9] Dombrovskiy K., Gvozdyak P.: Hydrobiological Journal, 2018, 54, No. 4, 63. https://doi.org/10.1615/ hydrobj.v54.i4.60

[10] Rylskyi O., Dombrovskyi K., Gvozdyak P.: Environmental problems, 2018, 3, No. 3, 167. (in Ukrainian)

[11] Vološyna O., Ryl's'kyj O. F.: "Moloda Nauka - 2017": zb. naukovych prac' studentiv, aspirantiv i molodych včenych u 4 t, Ukraïna, Zaporižžja 2017, 4, 25.

[12] Antypčuk A. F., Kirjejeva I. Ju.: Vodna Mikrobiolohija: Navč. Posib, Kondor, Kyïv 2005. (in Ukrainian) 